\title{
Inflation of water to the soil in the fields of drop irrigation
}

\author{
Bakir Serikbaev ${ }^{1 *}$, Abdukodir Butayarov ${ }^{2}$, Sardor Gulamov ${ }^{1}$, and Sanobar Dustnazarova ${ }^{1}$ \\ ${ }^{1}$ Tashkent Institute of Irrigation and Agricultural Mechanization Engineers, Tashkent, Uzbekistan \\ ${ }^{2}$ Termez State University, Surkhandarya, Uzbekistan
}

\begin{abstract}
The article presents theoretical and field experimental data on determining the rates of infiltration and filtration of irrigation water in the soil - grounds of the calculated layer in the cotton fields of the Dzharkurgan massif in the Surkhandarya region. Based on the established values of the rates of infiltration of irrigation water, the drip irrigation regime for cotton of the new Sultan variety has been determined, the parameters of the innovative drip irrigation technology have been determined.
\end{abstract}

\section{Introduction}

In the Surkhandarya region of the Republic of Uzbekistan, in recent years, innovative technology for irrigation of agricultural crops has been rapidly introduced; the introduction of innovative irrigation technology is shown in Figure 1 and table [1-3].

In Uzbekistan, intensive work is being carried out to introduce innovative methods, techniques, and technologies for the irrigation of agricultural crops, including drip irrigation of cotton, the total area of which, at present, is 43.0 thousand/ha [4-8]. In the Surkhandarya region, water introduction of conservation technology for irrigation of agricultural crops is shown in figure 1.

\footnotetext{
* Corresponding author: sbserikbayev@gmail.com
} 
Table 1. Information on the introduction of drip irrigation technology in 2019 in the Surkhandarya region

\begin{tabular}{|c|c|c|c|c|c|c|c|c|c|}
\hline \multirow[b]{2}{*}{ № } & \multirow[b]{2}{*}{ Name } & \multirow{2}{*}{$\begin{array}{c}\text { planne } \\
\mathrm{d} \text { area, } \\
\text { ha }\end{array}$} & \multicolumn{3}{|c|}{ planned area, ha } & \multirow{2}{*}{$\begin{array}{c}\text { area where } \\
\text { construction } \\
\text { and } \\
\text { installation } \\
\text { works are } \\
\text { completed, ha }\end{array}$} & \multicolumn{3}{|c|}{ others, ha } \\
\hline & & & $\begin{array}{l}\text { cotto } \\
\mathrm{n}, \text { ha }\end{array}$ & $\begin{array}{c}\text { garde } \\
\text { n } \\
\text { wall, } \\
\text { ha }\end{array}$ & $\begin{array}{l}\text { othe } \\
\text { rs, } \\
\text { ha }\end{array}$ & & $\begin{array}{c}\text { cotton, } \\
\text { ha }\end{array}$ & $\begin{array}{c}\text { garde } \\
\text { n } \\
\text { wall, } \\
\text { ha }\end{array}$ & $\begin{array}{c}\text { othe } \\
\text { rs, } \\
\text { ha }\end{array}$ \\
\hline 1 & Angor & 130 & & 80 & 50 & 200 & & 50 & 150 \\
\hline 2 & Baysun & 32 & & 32 & & & & & \\
\hline 3 & Denov & 2004 & 1970 & 34 & & 1970 & 1970 & & \\
\hline 4 & Jarkurgan & 752 & 60 & 692 & & 1860 & 60 & 1800 & \\
\hline 5 & Kizirik & 0 & & & & & & & \\
\hline 6 & $\begin{array}{c}\text { Kumkurg } \\
\text { an }\end{array}$ & 59 & & 59 & & 50 & & 50 & \\
\hline 7 & Muzrabad & 280 & & 280 & & & & & \\
\hline 8 & Altinsay & 332 & & 332 & & & & & \\
\hline 9 & Sariosio & 95 & & 95 & & & & & \\
\hline 10 & Termiz & 177 & & 127 & 50 & 38 & & 30 & 8 \\
\hline 11 & Uzun & 40 & & 40 & & & & & \\
\hline 12 & Sherabad & 69 & & 69 & & 110 & & 80 & 30 \\
\hline 13 & Shurchi & 75 & 45 & 30 & & 45 & 45 & & \\
\hline & Total & 4045 & 2075 & 1870 & 100 & 4273 & 2075 & 2010 & 188 \\
\hline
\end{tabular}

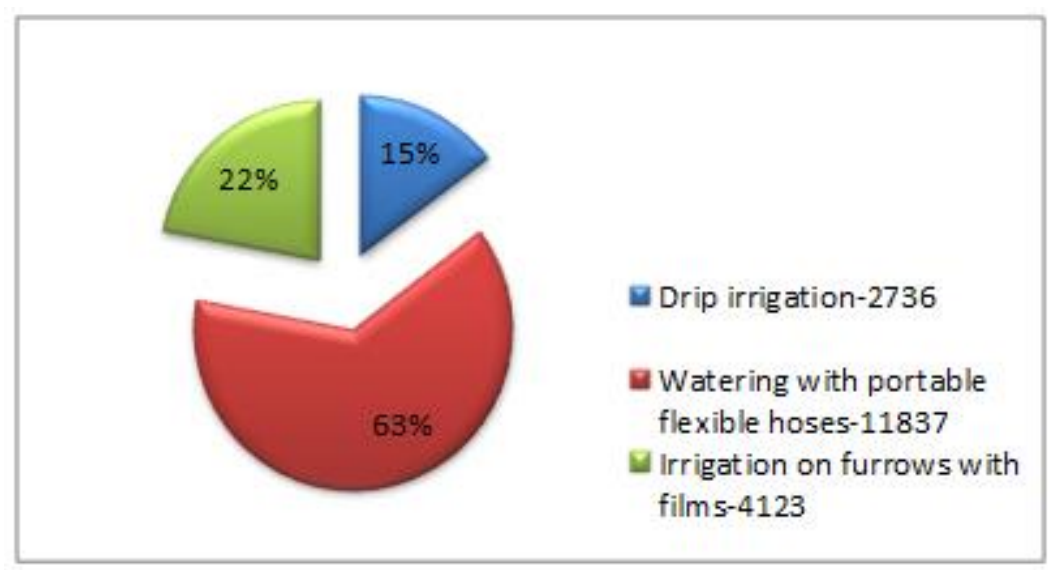

Fig. 1 Diagram of the introduction of water-saving technology in the Surkhandarya region

With drip irrigation of cotton of the new Sultan variety, there are still no scientific and practical recommendations for establishing an irrigation regime for the natural and economic conditions of the region under consideration [9-14].

\section{Materials and Methods}

The experimental plot with a drip irrigation area of 60 ha is located on the Dzharkurgan massif. The source of irrigation is the main canal "Amu-Zang", which takes irrigation water from the Amu Darya river. The surface of the experimental plot has a slope of $i=0.003$ - 
0.004; the soils are light in terms of mechanical composition, bulk density is $1.1-1.26 \mathrm{t} / \mathrm{m}^{3}$, sandy loam, and light loam, not saline, are widespread, the depth of groundwater during the year varies from $2.6-2.8$ to $3.1-3.5 \mathrm{~m}$.

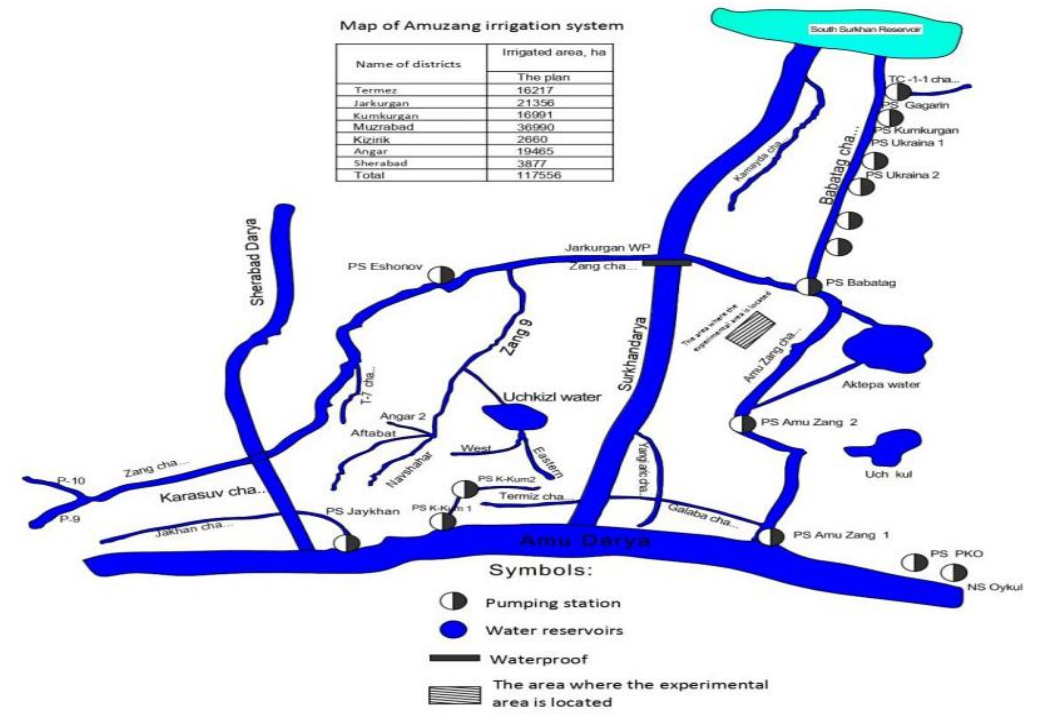

Fig. 2. The location of the experimental plot is shown in

The experimental plot is typical for climatic, soil, geological, hydrogeological, hydrological, and economic conditions of the Dzharkurgan irrigation massif; it was selected based on the methods of V.V. Shabanov and E.P. Rudachenko [15-18].

In the case of drip irrigation, cotton irrigation was carried out through an extensive network of pipelines through special micro-outlets directly to the root zone, maintaining soil moisture throughout the growing season at a level close to the calculated one. At the same time, this created the possibility of a continuous supply of water to plants and nutrients. The estimated drip flow rate was $3.2-3.6 \mathrm{l} / \mathrm{h}$.

The main methodological provisions are based on theoretical and experimental studies, a broad generalization of the practice of drip irrigation of cotton by the research of TIIIMSKH, NIISSAVKH, NIIIVP, TashSAU, VNIIGIM named after A.N. Kostyakov, Volgograd State Autonomous Institution, Moscow State Agrarian University named after Timiryazeva et al. Field studies were carried out using standard and specially developed methods, the reliability of the results was evaluated by verifying the results of theoretical and field studies [18-26].

\section{Results and Discussion}

In the widespread introduction of resource-saving irrigation methods and techniques, and with a wise choice of crop irrigation technology, one of the main factors is the soil reclamation conditions of the irrigated massif. In the Surkhandarya region of the Dzharkurgan district, LLC "Surkhon Sifat Textel" Dienov, a branch of the Dzharkurgan array of cotton drip irrigation, we conducted field experimental studies to establish the value of the infiltration and filtration of irrigation water in the soil of the settlement layer. The quality of irrigation, maintaining the soil structure, maintaining the reclamation ecological state of the land, the duration of irrigation, the value of the elementary irrigation rate, the number of irrigations of agricultural crops by interconnections. 
With all irrigation methods by the rabbits of intra-soil and sub-irrigation, water is supplied to the soil surface and is absorbed into it very quickly, then more slowly. The absorption process is characterized by the depth of soaking and speed, infiltration by which we mean the height of the words of water absorbed into the soil per unit of time. According to A.N. Kostyakov, it changes in time according to:

$$
v=\frac{v_{1}}{t^{\alpha}}
$$

Where $v_{t}$ is the absorption rate at a given point at time $\mathrm{t}$; $t$ is the duration of absorption; $v_{1}$ is absorption rate at the end of the first unit of time; $\mathrm{t}^{\mathrm{a}}$ is exponent, varying from 0.3 to 0.8 , depending on the nature of the soil and its initial moisture content.

$\alpha$ is an indicator of the degree of the infiltration curve.

$$
\alpha=\frac{L_{g} \cdot v_{t}-L_{g} \cdot v_{f}}{L_{g} \cdot t-L_{g} \cdot t_{f}}
$$

Where $\mathrm{v}_{\mathrm{t}}$ is infiltration rate at time $\mathrm{t}, \mathrm{m} / \mathrm{h}$.

The average absorption rate over time $t$ is equal to:

$$
v_{t_{c r}}=\frac{1}{t} \int_{0}^{t} \cdot \frac{v_{1}}{t^{\alpha}} \cdot d \cdot t=\frac{v_{1}}{1-\alpha} \cdot \frac{1}{t^{\alpha}}=\frac{v_{1}}{t^{\alpha}}
$$

$v_{1}$ is the absorption rate, the average for the first unit of time.

Values for different soils vary from 0.005 to $0.03 \mathrm{~m} / \mathrm{min}$, and, for the same soil, by the end of the growing season, it decreases by 1.5 - 2 times. For most soil types in Uzbekistan, an average value of about 0.5 is recommended. The main disadvantage of the formula A.N.Kostyakovo is that when $t-\infty$ absorption rate $v_{t} \rightarrow \mathrm{O}$ Basically, in the experimental determination of quantities $v_{1}$ and $\alpha$ and practically limited values $\mathrm{t}$ This formula describes the process quite well. The time course of the absorption process depends not only on the nature of the soil and its moisture but also on several other factors: pressure gradients, soil swelling, destruction of soil aggregates, compaction and swimming of pores, colmatization, and closing of cracks, type of soil surface, and the presence of soil or other salts, water temperature. The first stage of the infiltration process - inflation is characterized by water movement in the soil along cracks, large voids, the swaths of the earth swarms, root passages. The hydromechanical solution of the one-dimensional problem of absorbing water into the soil, which allows one to determine the depth of soaking for different points in time, was given by V.V. Vedernikov. The equation obtained by him has the form:

$$
\frac{R_{f} \cdot t}{m^{1} \cdot(h+H)}=\frac{y}{h+H_{k}}-\ln \left(1+\frac{y}{h+H_{k}}\right)
$$


Where $h$ is depth of water on the surface of the soil or soil; $H_{k}$ is height of capillary rise; $y$ is wetting depth; $R_{f}$ is filtration coefficient; $m^{1}$ is free porosity or coefficient of lack of saturation; $t$ is duration of infiltration.

Over time $t$, a layer of water is absorbed into the soil:

For uniform moistening of the soil over the entire area of the irrigated area, the absorption time must be the same for each point of the dropper, which provides sufficient uniformity of moisture calculated for the depth of the soil.

In logarithmic coordinates, the absorption curve during the infiltration period $\left(v=\frac{v_{1}}{t^{\alpha}}\right)$ is a straight line

$$
t_{g} \cdot v_{t}=t_{g} \cdot v_{1}-\alpha \cdot t_{g} \cdot t
$$

I.G. Aliev and N.F. Bonchkovsky proposed formulas $k_{0}=k_{c p}(10 P)^{\alpha}$

Where $P=0.5^{0.1694}$

$$
k_{a v}=\frac{k_{1} \cdot t_{1}+k_{f} \cdot t_{2}}{t}
$$

Where $k_{a v}$ is average rate of absorption during the period of infiltration; $\mathrm{t}_{1}$ is time of infiltration absorption, $\mathrm{m} / \mathrm{h} ; \mathrm{t}_{2}$ is filtration absorption time, $\mathrm{m} / \mathrm{h}$.

According to this technique, the values of water permeability of the soil in the Dzharkurgan massif of the Surkhandarya region were determined.

In the experimental plot with medium loamy non-greasy soils, the rate of water absorption at the end of the first hour at the beginning of the growing season was 0.056 $\mathrm{m} / \mathrm{h}$, in the middle of the growing season $-0.042 \mathrm{~m} / \mathrm{h}$, the filtration coefficient -0.017 and $0.014 \mathrm{~m} / \mathrm{h}$.

The rate of water infiltration into the soil at the beginning and middle of the growing season, $\mathrm{m} / \mathrm{h}$, is clear from the experimental plot in 2019.

\begin{tabular}{|c|c|c|}
\hline \multirow{2}{*}{ Absorption time, $\mathrm{h}$} & \multicolumn{2}{|c|}{ Dzharkurgan massif, $\mathrm{m} /$ hour } \\
\cline { 2 - 3 } & In the beginning & In the middle \\
\hline 0.5 & 0.084 & 0.064 \\
\hline 1 & 0.056 & 0.042 \\
\hline 2 & 0.034 & 0.028 \\
\hline 3 & 0.024 & 0.022 \\
\hline 4 & 0.021 & 0.019 \\
\hline 5 & 0.020 & 0.018 \\
\hline 6 & 0.019 & 0.017 \\
\hline 7 & 0.018 & 0.015 \\
\hline 8 & 0.017 & 0.015 \\
\hline 9 & 0.017 & 0.014 \\
\hline 10 & 0.017 & 0.014 \\
\hline 11 & 0.017 & 0.014 \\
\hline
\end{tabular}


The rate of water infiltration into the soil at the beginning and middle of the growing season, $\mathrm{m} / \mathrm{h}$, is clear from the experimental plot in 2019.

\begin{tabular}{|c|c|c|}
\hline \multirow{2}{*}{ Absorption time, $\mathrm{h}$} & \multicolumn{2}{|c|}{ Dzharkurgan massif, $\mathrm{m} /$ hour } \\
\cline { 2 - 3 } & In the beginning & In the middle \\
\hline 0.5 & 0.084 & 0.064 \\
\hline 1 & 0.056 & 0.042 \\
\hline 2 & 0.034 & 0.028 \\
\hline 3 & 0.024 & 0.022 \\
\hline 4 & 0.021 & 0.019 \\
\hline 5 & 0.020 & 0.018 \\
\hline 6 & 0.019 & 0.017 \\
\hline 7 & 0.018 & 0.015 \\
\hline 8 & 0.017 & 0.015 \\
\hline 9 & 0.017 & 0.014 \\
\hline 10 & 0.017 & 0.014 \\
\hline 11 & 0.017 & 0.014 \\
\hline
\end{tabular}

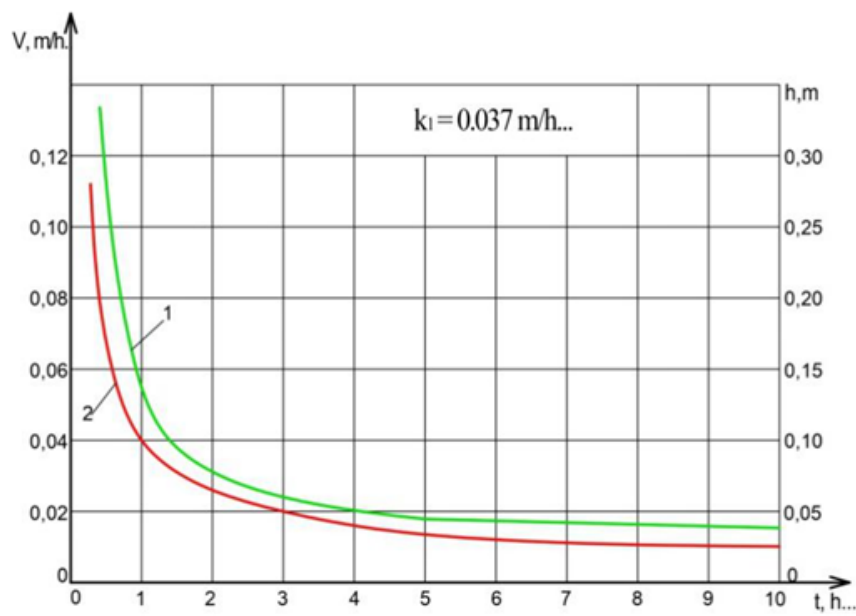

Fig. 3. the absorption rate of water in irrigating cotton

\section{Conclusions}

1. The value of the infiltration of irrigation water into the soil - the soil of the calculated layer on the drip irrigation lands of cotton depends not only on the type, soil type of soil conditions and its degree of moisture but also on several other factors: pressure gradients, soil swelling, destruction of soil aggregates, compaction and swimming pore, clogging and closing cracks, water temperature, and friend.

2. Based on the results of field experimental studies, we have established the values of infiltration, inflation of the first stage of infiltration of irrigation water into the calculated layer of soil and soils. Values: $\mathrm{v}_{\mathrm{o}}=0.53 \mathrm{~m} / \mathrm{h}, \mathrm{v}_{1}=0.053 \mathrm{~m} / \mathrm{h}, \mathrm{v}_{\mathrm{cp}}=0.042$ $\mathrm{m} / \mathrm{h}$,

3. The values of the rate of irrigation water infiltration into the soil - soils under drip irrigation of cotton were determined, which allowed us to determine the depth of the settlement layer depending on their development phase. 
With drip irrigation of cotton, only the soil is moistened - the soils of the root layer. The value of the calculated layer of the rooting layer was; $0.5 / 1.0 \mathrm{~m}$ depending on their phase of development and the size of water consumption of cotton.

\section{References}

1. Aliyev I.G., Bonchkovsky N.F. Determination of the optimal elements of furrow irrigation technique // Transactions of VNIIGiM, Moscow (1970) st. 188 - 212.

2. Bagrov M.N., Kruzhilin N.P. progressive crop irrigation technology. // Moscow Kolos, 1980208.

3. Dospekhov B.A. The methodology of field experience.// M .: Kolos - (1973), Art. 7778.

4. Kostyakov A.N. Fundamentals of Land Reclamation. M: Selkhozgiz, (1960). Article 522.

5. Laktaev N.T. Watering the cotton. M .: Kolos, (1978). Article 175.

6. Laktaev N.T. Improving the irrigation of cotton. Abstract. dis. for a job. student Doctors of technical science. 06.01.02. m., (1980).

7. Natalchuk M.F., Akhmedov H.A., Olgarenko V.I. Operation of irrigation and drainage systems. M.: Kolos, (1983).

8. Peregudov V.N. Planning multifactor field experiments with fertilizers and mathematical processing of their results. M .: Kolos, (1978) g. 183.

9. Rode A.A. Fundamentals of the doctrine of soil moisture. T. 2. Methods of studying the water regime of soils. M .: Gidrometeoizdat, Article 287. (1969).

10. Alpatiev S.M. Guidelines for calculating the irrigation regime of agricultural crops based on the bioclimatic method. // Kiev (1967), Art. 75 - 79.

11. Serikbaev B.S., Baraev F.A., Fulomov S.B. Reliability of drip irrigation systems. //"IRRIGATSIYA va MELIORATSIYA" magazine. No. 4 (10). Toshkent (2017).S. $10-11$.

12. Reference book "Irrigation" (edited by B. B. Shumakov), - Moscow: Agroizdat, (1999), $113 \mathrm{p}$.

13. Serikbaev B.S., Butayarov A.T. Calculation of the drip irrigation regime for cotton of the new Sultan cultivar. //"IRRIGATSIYA va MELIORATSIYA" magazine. No. 2 (16). Toshkent (2019).S. 10-14.

14. Butayarov A.T. Improvement of water use in the farms of the Amu - Surkhan International Airport. // Special issue of "AGRO ILM" Magazine № 4. Tashkent (2019). 79 - 80 p.

15. Butayarov A.T. Reliability of farm irrigation and reclamation systems. // Journal of Agriculture and Water Resources of Uzbekistan. No. 8. Tashkent (2019). 44 b.

16. Serikbaev BS, Sherov AG Operation of irrigation and drainage systems. Tashkent (2020).

17. Serikbaev B.S., Baraev F.A., Gulomov S.B. "Reliability of drip irrigation systems."//"IRRIGATSIYA va MELIORATSIYA" magazine. No. 4 (10). Toshkent (2017).S. 10-14.

18. Gulamov S.B. "Drip irrigation systems, calculation method." "ToshDTU Khabarlari" magazines No. 1-2. Toshkent (2011).st. 13-14.

19. Baraev F.A. Gadaev NN, Sarimsokov MM, Abduraupov R., Gulomov SB, "Methods of irrigation and development of drip irrigation systems in Uzbekistan" Kazakhstan Taraz, November 19-20, 2015. Art. 44-46.

21. Baraev F.A. Umurzokov U.P. Sherov G. The new generation low-pressure drip irrigation system." Moscow (2013). 66-68.

21. Matyakubov B., Begmatov I., Raimova I. and Teplova G. Factors for the efficient use 
of water distribution facilities. IOP Conf. Ser. Mater. Sci. Eng. 883, 012025 (2020).

22. Uralov B., Rakhmatov N., Khidirov S., Uljaev F., Raimova I. Hydraulic modes of damless water intake. IOP Conf. Ser. Mater. Sci. Eng. 1030(1), 012123 (2021)

23. Rakhmonov S., Umurzakov U., Rakhmonov K., Bozarov I., Karamatov O. Land use and land cover change in Khorezm, Uzbekistan. E3S Web of Conferences, 227, 01002, (2021)

24. Umurzakov U., Mamatov F., Aldoshin N., Mirzaev B. Exploration of tillage technologies in the Republic of Uzbekistan, IOP Conference Series, Earth and Environmental Science, 614(1), 012168, (2020)

25. Umurzakov U., and Djuraev B. Prediction of prices for agricultural products through markov chain model, International Journal of Psychosocial Rehabilitation, 24(3), pp. 293-303, (2020)

26. Umurzakov U., Mirzaev B., Salahodjaev R., Isaeva A., and Tosheva S. Energy consumption and economic growth: Evidence from post-communist countries. International Journal of Energy Economics and Policy, 10(6), pp. 59-65, (2020) 